\title{
A Tale of Two Archives, Two Eras: The UC Berkeley Folklore Archives $\&$ The USC Digital Folklore Archives
}

\author{
Tok Thompson \\ University of Southern California \\ tokthomp@usc.edu
}

\begin{abstract}
This article examines two recent folklore archives, both in California: the UC Berkeley Folklore Archives, founded by Alan Dundes, and the USC Digital Folklore Archives, which I initiated just a few years ago. In this analysis, I attempt to locate these archives not only as sites of performances, but also as performances themselves, with particular participants, contexts, and impacts. The UC Berkeley Archive arose in a time of social upheaval in America, and in American folkloristics, while the USC Archives emerged as part and parcel of the digital, global shift in human culture. Archives are a fundamental part of folklore studies, and studying them allows for a fuller understanding of the discipline, and of the discipline's role in the larger society in which it functions, and which it often claims to represent. It is hoped that this brief account may be of some value in understanding how the study of folklore continues to adapt, and how archives can continue to be important and relevant in our quickly changing world.
\end{abstract}

KEYWORDS

Archives; Alan Dundes; California; Cyberlore; Global 


\section{RESUM}

Aquest article estudia dos arxius de folklore recents de California: els Arxius de Folklore de la Universitat de California Berkeley, fundats per Alan Dundes, i els Arxius de Folklore Digitals de la Universitat del Sud de California, que vaig posar en marxa fa pocs anys. En aquesta anàlisi, el meu objectiu és situar aquests arxius no només com a llocs d'actuacions, sinó també com a actuacions en sí amb participants, contextos $i$ influències. L'Arxiu de la Universitat de California Berkeley va sorgir en una època d'agitació social a Amèrica i a la folklorística americana, mentre que els Arxius de la Universitat del Sud de California van aparèixer com a part integral del canvi digital $i$ global de la cultura humana. Els arxius són una part fonamental dels estudis de folklore $i$ el fet d'estudiar-los permet entendre més la disciplina i el paper que té en la societat que l'envolta i en què funciona i que sovint diu que representa. Aquest informe breu pretén servir per entendre com segueixen adaptant-se els estudis de folklore i com els arxius poden continuar sent important i rellevants per a un món que està canviant tan de pressa.

\section{PARAULES CLAU}

Arxius; Alan Dundes; California; cyberlore; global

REBUT: 09/II/2OI6 | ACCEPTAT: OI/I2/20I6

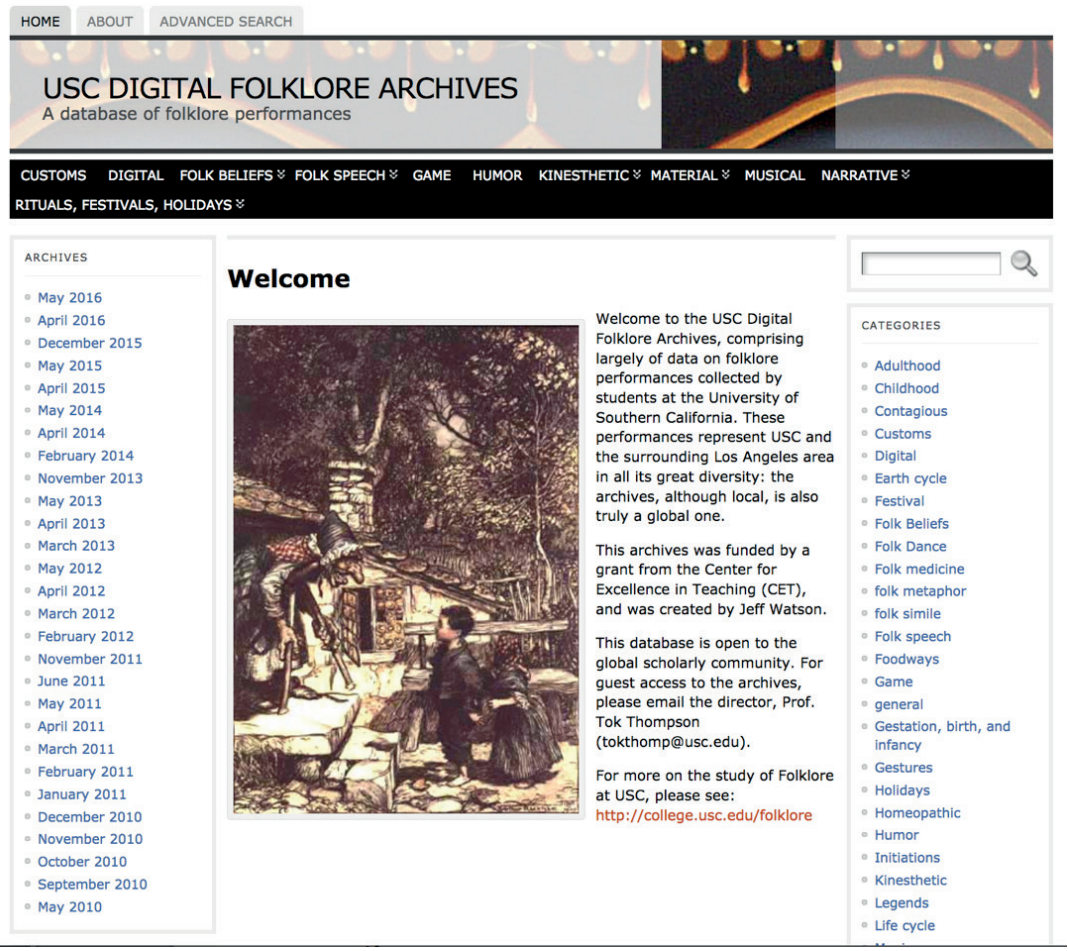




\section{Introduction}

Finnish Folklorist Pertti Antonnen wrote that archives are "tools of modernity" which utilize the traditional past in order to create modernity. According to Antonnen (2005: 94):

The traditional folkloristic strategy is to folklorize cultural practices deemed traditional, make them collectibles, and put them in large quantities in storage or on display in archives and museums to represent the national cultural metonymically and to make a symbolic claim for the preservation of the nation's cultural heritage. According to such an 'archive strategy', cultural identity is best protected and argued for by depositing textual representations of it in the archive and then producing selected and edited materials in books for the consuming and reading public.

Similarly, Jacques Derrida, in his work Archive Fever (1996), stated that the archons are those who are positioned to speak from the archives, to interpret the sacred texts of the past in a role reminiscent of sacred high priests guarding religious relics. Gayatri Spivak, who translated Derrida's De la grammatoalogie into English, used Derrida's view of archives to formulate her famous work "Can the Sub-Altern Speak?" (I992). This work questioned the extreme disadvantaged position of Indian women, due to the macro power structures of global colonial politics ("white men saving brown women from brown men"), and also to the local power structures, which invoked social inequalities particularly on the basis of class and gender. Both macro and micro power inequalities relied on interpretations of sacred ancient Hindu texts for their legitimacy: it was the power of the archons that allowed hegemonic controlled representation, and hence law, in imposing social inequalities.

The question of who gets to select the symbols, guard them, and interpret them has a great deal to do with society, politics, and power.

As Charles Briggs (I993: 387) put it:

Theories and methodologies... are coming to be regarded as cultural products that are deeply embedded in the social, political, and historical circumstances of their production and reception. Cultural representation plays a crucial role in scholarship, and the fruits of academic research are thus part and parcel of the cultural policies that they examine.

Examining the role of archives is, then, an important part of the critical selfawareness of folklore studies, and its relation to its wider social setting. In this paper, I describe two newer archives with which I have been involved, both in California: the UC Berkeley Folklore Archive, dating from the I96os, emphasizes contemporary and international aspects; the USC Digital Folklore Archives, a product of the new millennium, is firmly embedded in global cyber discourse.

Both of these archives can be viewed as products of their time and place, and they reflect trends in American folklore scholarship, generally. As such, an overview of both these examples from California reflects the general move in American folkloristics away from the "phantoms of Romantic Nationalism" (as per the Abrahams' I993 article). However, it also increasingly highlights the notion of the archives as performances, situated in time and place. 


\section{Folklore at Berkeley}

The UC Berkeley Folklore Archives is a tiny little place that is deservedly famous and has played an influential role in Folklore Studies in America - and, indeed, around the world - for many decades. Alan Dundes founded the archives to supplement his work and teaching as a professor of Folklore at UC Berkeley. The collections are nearly all derived from his seminal class, Forms of Folklore. Both the class and the archives continue forcefully even after Prof. Dundes' untimely passing in 2005, with the Alan Dundes Distinguished Professor in Folklore Charles Briggs now directing the Folklore Program, and the archives.

For many years, Dundes required each student to submit 40 items of folklore, with each entry duly noting informants' names, ages, occupations, ancestry, and all sorts of other data, in addition to the folklore itself. In I979, the ever-growing archives were moved into their current home at II2 Kroeber Hall (Zumwalt 2OI4: I42). The sizeable requirement of 40 items, coupled with the popularity of Dundes' classes (several hundred students every term), and the length of time he taught the class created a tremendous scholarly collection, which remains eminently usable for all those who visit.

The Berkeley Folklore Archives follows the standard guidelines of the discipline in terms of how to collect folklore. The size, organization, and singularity of the collection make it quite unique: while many archives collect their material in several different formats, Berkeley's consists almost exclusively of the standard paper size $8 \frac{1}{2} \mathrm{X}$ II inches.

The collection is housed in a relatively small, windowless room, with double doors framed by tall, imposing totem poles, deep in the heart of Kroeber Hall, across from the Kroeber Anthropology Museum, and downstairs from the Anthropology department with its massive anthropology library. Inside, a large, central work table for students is surrounded by a narrow walk space which, in turn, is surrounded by filing cabinets overflowing with collections of folklore. On top of the cabinets rest voluminous manila envelopes of documents waiting to be filed.

Most professors had their office on the third floor, but Dundes remained on the second, next to the semi-secret staircase that connected his office to the archives below. As perhaps the single most influential scholar of his generation, Prof. Dundes' phenomenal career is inextricably entwined with the origin of the UC Berkeley Folklore Archives. ${ }^{\mathrm{I}}$ To explain the archives, then, let me tell you the story of its founder, of course, but also of the particular place, time, and zeitgeist.

\subsection{Peace, Love, and Folklore}

Berkeley, California, I96os: filled with the best and brightest of California, and with free tuition for all students, the University supposedly represented America's best modern foot forward. The America of the I96os strongly believed in the future progress of society through education, and college numbers exploded. It was the American baby boom, and the boomers quickly proved what a vast

I. For more on the UC Berkeley Folklore Archives, see Bendix, in Bendix \& Lévy-Zumwalt (I995). 
young, enthusiastic and optimistic demographic could do. As Bob Dylan sang in the coffeehouse on Berkeley campus, "The Times, They Are a' Changin”.

However, American society had some serious problems that were an obstacle to social progress. Racism was one of the most obvious. Blacks in America were being routinely targeted for harassment and generally treated as second-class citizens. Martin Luther King Jr. was assassinated in I969, and people began talking about the Black Panthers, who had been providing lunches to schoolchildren in impoverished inner-city schools, and who had increasingly taken up patrolling their own streets, armed with machine guns. In the south, white nationalists launched concerted actions to deny black citizens the vote, and the civil rights movement was in full swing.

College students demanded freedom of speech, and made themselves heard on various progressive issues. They burned Vietnam War draft cards in front of the University's Sproul Hall, and turned an abandoned parking lot into People's Park for the citizens of the world. On the warm spring day of May I5, I969, the governor Ronald Reagan called out the California national guard to tear gas and beat 6,000 of them.

Working his way across campus through student protestors and riot police, surrounded by distant shouting and the lingering scent of tear gas was a young, politically progressive Berkeley professor. By I969, Alan Dundes had already been at Berkeley for 6 years, and a professor for 7 . Although still young, he was already a giant in the field.

He had been trained at Indiana University at Bloomington, under the tutelage of Richard Dorson. Many of his student colleagues had been motivated by the role that folk music played in civil protest. Folk music was seen as a counterhegemonic force in America, bringing together the various protest groups - the anti-war, anti-poverty, anti-racist, and generally politically progressive ideologies in America at the time. Many folklorists of the time were also accomplished folk musicians and accomplished protestors. By I969 folk music was still around, but many of the protests had turned darker. Guns were being carried instead of flowers, and crazy loud electric guitars were replacing sweet folk harmonies. Push was turning to shove.

In all this, the "young turks" of American folklore were reshaping what folklore was all about. Although folklore was one of the favorite subjects of many ethnic nationalists and white supremacists, the young folklore scholars were turning their gaze to other subjects: African-American folklore, Hispanic folklore, and the folklore of many other ethnic groups. The field was rapidly expanding towards a more inclusive sampling of the various peoples of America. Of all the newer scholars who were shaking up the discipline, however, it was the slightly tear-gassed professor who continued to make the most waves.

The main problem was easy for him to see. In America, folklore was not taken seriously as a discipline. How could Dundes, or any of his colleagues, make any headway in using folklore to help improve the world, if the discipline - and the subject matter - was not taken seriously to begin with? If folklore continued to be thought of as a lack of scientific understanding, or rambling stories of underemployed farm hands, then not only would the entire discipline continue to wither away into oblivion, at best occasionally buoyed by nationalist politicians, but the contemporary world would also miss out on hearing the multitudes of 
voices, from the folk, the hoi polloi, and all those outside the rigid gates of power and authority.

Dundes addressed many of the contemporary social issues directly in his work. For example, at the height of racial tensions, he published works on the racist jokes that white Americans told, revealing the pervasiveness of coddled racism still extant in American society. ${ }^{2}$ Was this folklore, some would invariably ask? Yes, of course, answered Prof Dundes, who would then go on to reveal the evenmore revolutionary theoretical underpinnings of his research, designed not only to widen the field, but also to present it on a sound theoretical - even scientific, he would say -basis.

You see, he would say, folklore, to be a science, has to be theoretically selfinformed. We could start with the subject matter - how do we define folklore, theoretically speaking? What do legends and riddles, proverbs and music have in common? Where many scholars might have been secure never asking this question, or answering the question with a mere list of items, Dundes demanded further theoretical scrutiny in his own work and in the work of others. ${ }^{3}$

Through this insistence, the study of folklore became increasingly applicable to contemporary issues. Dundes published work on many eras and groups, and his books might include one chapter on an ancient Egyptian tale alongside one on American male chauvinist jokes. It was important, Dundes realized, not to be too starry-eyed and romantic: folklore does reflect the society, revealing warts as well as beauty marks. Racism, sexual frustration and xenophobia are all parts of the folk, too. Folklore studies was not about projecting or defining a national past, and hence identity, but rather about learning other cultures, about confronting societal ills, and, above all, about making "the unconscious, conscious" (Dundes 2002: I37).

\subsection{The Archives}

Although an indefatigable library and archival researcher, Dundes was keenly aware of the relative paucity of materials on contemporary cultural practices collected in a scientific, comparable manner. The Berkeley Archive was Dundes' main data set which was to inform all the contributions he made to the field of folklore, the fuel for his fire. Dundes would read, and grade, each and every student submission. The collection swelled as more and more submissions were made, all stored in manila envelopes and filing cabinets.

Organizing the data was limited by the fact that it was a paper collection: crammed into file cabinets, how should it be organized? Which papers should go where? The method Dundes selected began with the ethnic or ethno-national category, which was then broken down by genre, and finally by item type. This worked well if one's interests were firmly lodged in this paradigm. For example, it was quite easy to find out about Spanish wedding rituals.

But these areas of interest were not broken down by region (Catalan versus Galician, for example, was largely non-existent). Also, what if your interest was

2. For example, see his I97 "A Study of Ethnic Slurs", and his I977 "The Curious Case of the Wide-mouth Frog".

3. See, for example, Dundes' Invited Presidential Plenary Address at the 2004 American Folklore Society meeting, printed in the Journal of American Folklore (2005). 
sparked by a particular item you had never seen before, and you wanted to make that your focus? The links between, say, Spanish and Portuguese wedding customs were not always obvious because they were in separate filing cabinets in different parts of the room. You could look them up, but since you couldn't search by item across multiple locations, you might conceivably have to look through many countries before finding out that a particular wedding custom was also very strong in Italy. There is a strange irony, here, that the ethno-nationalism whose influence on folklore Dundes consistently decried, was embedded and reified in the structure of the archive itself. The nation-states had top billing, and the items were duly represented inside the nation-states and ethnicity markers, a model representation of the main goals of ethno-nationalism.

This made for some frustrating searches, particularly on a comparative topic. It also involved lots of people poring over files together in the same physical space, and sharing in those moments of excitement, discovery, amusement, and other emotions. Some of the undergraduates who did the filing would go on to become major folklorists and/or archivists themselves. The graduate student archivist(s) were also there with other researchers (graduate students, undergraduates, and both local and foreign visiting scholars). We would have talks, pizza parties, and the "item of the week" where one folder would be picked out for discussion (resulting in at least one of my published papers). Graduate students would give mock presentations before going to academic conferences. Visiting scholars from around the world would give guest talks, and get to know the Berkeley students. Friendships were forged there, romances bloomed and died, and generations of folklorists got to know each other and each other's work.

All of this social and academic activity took place around the data itself, which, following Dundes' exhortations, was international in scope, ${ }^{4}$ yet clearly, at the same time, American in outlook.

The archives reflected the shift in folklore studies in America, as folklore reinvented itself away from being depository of national cultural treasures of the past, as was common in European archives. Instead, it revealed and embraced a model of American multiculturalism. In this way, too, the Berkeley Folklore Archive instantiated the vision of the "new folklore" of I96os America, and, indeed, the "new America" - a vision based not on primordial ethno-nationalism (which never worked very well in the US, for obvious reasons) - and moved towards America as a living symbol of diversity and inter-cultural contact.

\subsection{A new epoch comes creeping in, and a new journal emerges}

During my graduate studies there, the world began to change. Although the internet had, in theory, begun several years previously, it was during my time there that the initial explosion in people connected and material available became widely noticed and appreciated. The year 2000 marks the year that most Americans gained internet access, making the shift from the internet as a slightlygeeky place for the technologically consumed to the focus of cultural exchange.

4. "The first thing I do when I get a book is look at the bibliography. If it's all in English, it's worthless" (Dundes, quoted in Bendix I995: 56). 
Dundes had already published several studies on "Xerox lore", which explored how folklore was using increasingly-affordable publishing technologies. As he surmised, "So technology isn't stamping out folklore; rather it is becoming a vital factor in the transmission of folklore and it is providing an exciting source of inspiration for the generation of new folklore" (I980: I7). Some folklorists had already noted that early email and usenet material was folkloric as well. ${ }^{5}$ However, the early internet examples were limited somewhat by the relative restrictions of their genre - the internet was still largely textual. The explosion of the phenomenological potential of the internet, and its ascendance as the overwhelming paradigm of the new age, was just setting in.

As a graduate student at the time, I was already an early believer in the publishing potential of the internet, and I became interested in creating a freelyavailable, "gold open access" (although the term didn't exist at the time), and truly international folklore-based journal. Hatched with other denizens of the archives (and the café Strada right across the street - these two places were linked in constant back-and-forth movements of people and coffee), Cultural Analysis: An Interdisciplinary Forum on Folklore and Popular Culture was born, and began publishing in 2000, marking the new millennium. With seed money from the Doreen B. Townsend grant, we were able to print Ioo copies, and mail them to major libraries and institutions for free, while we simultaneously made our pdfs and html versions freely available online. This strategy was a major success, and the journal quickly became widely disseminated, highly cited, and increasingly well-ranked in terms of global scholarship. ${ }^{6}$ Its beginnings, however, were in the archives itself, emerging from the somewhat frenzied interactions of agents, discourses, and zeitgeists, and it made its home in the archives for the first I 2 years of its publication, engaged in its quest for global cyber discourse.

\section{Folklore at USC}

After obtaining my PhD at Berkeley in Anthropology, under the mentorship of Prof. Dundes, I began my own career work, first in a postdoctoral position at Trinity College, in Dublin, Ireland, and then, in 2005, at the department of Anthropology in the University of Southern California, where I managed to institute various folklore courses, a folklore minor, and a digital folklore archive, now available at <http://folklore.usc.edu/>.

The design of the USC Archives is deeply indebted to UC Berkeley Archives. Like Dundes' program, it is an integral part of my introduction to folklore class, which provides most of the material. Yet, in contrast to the Berkeley Folklore Archives, it is a completely cyber archive and exists solely online.

Initially, I was at a loss as to how to build such an archive: I had seen various protocols and design certifications, and I was far from an expert. Luckily, by asking around my university, I was able to enlist a graduate student, Jeff Watson (now a faculty member at USC). His solution was simple, elegant, and eminently do-able. He suggested that the archive be based on WordPress software, the software used

5. See, e.g. Kirshenblatt-Gimblett in Bendix (1995).

6. Cultural Analysis is now associated with SIEF (Société Internationale d'Ethnologie et du Folklore / International Society for Folklore and Ethnology). 
in many blogs. It provides an easy way to structure a fully-functioning folklore archive and with just a few widget modifications, the USC Folklore Archives came into being. Students submit their collections directly to the online archives, and after I have reviewed them, I make their collections viewable (I "publish" them, in WordPress parlance).

As well as typing in their textual report, students also filled out fields with information about the piece, and their informant. This allows several top-down classifications. The genre fields are given on the home page: narrative genres are one top-level category, for example. Tags based on keywords are automatically generated, and are also a handy way of searching and navigating the material. Images are easy to include, as are audio-visual clips, subject only to the size restrictions of the server.

As I got to know this new, very different archive, I became aware of various things. The main change was that there was no longer any need for a top-level category based on ethno-nationalism. The national categories were still present as fields in the archive entries, so they were easily searchable: if you wanted to find "Bulgarian proverbs", all you had to do was type in "Bulgarian proverbs" in the search fields and you would get your results. But if you wanted to find something else ("proverbs about wisdom", for example) that, too, was also available. I began to become aware of the subtle ways - in addition to the major ways - that digitization shapes our perception of identity, particularly that of the nation-state identities viz a viz emerging global ones.

After the difficulties of searching the paper archives, searching the digital one was so easy that the search function, for me, replaced the "browsing by category" experience: instead of meandering my way through the material, I now jump straight to the data I'm looking for. It's much more efficient, although at times meandering through materials is a valuable scholarly pursuit, which forces us to face the unexpected. The speed of the search takes away some of the serendipity of the process, in exchange for increased efficiency.

There were other differences, as well. Prodded by student interest, I have increasingly allowed a percentage of their collections (20 items each) to be "cyber-lore", or folklore largely located via the internet. These are some of the most compelling, and contemporary, items because they provide an interesting slant on the emerging worldviews of the first generation of these "digital natives".

One shortcoming of a digital archive, or at least the current version of the USC Folklore Archives, is that there is no social space. Unlike the Berkeley Archive, with all its bodies and filing cabinets crowded together in a communal phenomenological and ideological unity, there are no pizza parties or guest lectures. The USC archives are solely cyber, and cyberly solo. The differences between the two experiences are pronounced. For the first eight years, access to the archives was restricted to authorized users (mostly the students in my folklore classes, but occasional "guest scholars" as well). Being "in" the archives was an inherently solitary experience: even if there was someone else "in the archives" at the same time, you didn't know. Instead, visiting the archives had a "graveyard silence" of the ghostly sort: although alone, you were constantly exposed to other de-temporal voices of the collector, the informant, the informant's informant, and others. 
After the material had been built up for eight years, the archives accidentally became publically viewable after a WordPress update failed to load one of the extensions. Since that time, I've "left the doors open" to the general internet community. The USC folklore archives can now be - and is - read by people all over the planet. Opening the doors has also opened it up to full searchability, and this allows all sorts of people to find our data in Google and other top-level search engines, particularly those seeking information on obscure items, characters, or genres. Not surprisingly, this has brought about a marked rise in people making use of the archive, and the number of citations in all sorts of other studies. In short, it has shifted from being a wholly scholarly enterprise to one aligned with the goals of producing scholarly knowledge for the whole human community. Although it has been a move out of the secure confines of the ivory tower, it feels in line with the overall current emphasis on the freedom of information, and the role of the university in global human society, as well as the notion that folklore belongs, ultimately, to the folk, not just the scholar.

So, the material (at present only 7,4I6 items, but growing at a steady rate), is now available to the online global community. Similarly, the structure of the USC Folklore Archives is a highly replicable model; any institution could easily build their own by using it as a model. Older archival materials could be digitized and easily added to the archives as well. At least one other university, Pennsylvania State University, has taken the initiative of creating their own folklore archive using this template.

Across the globe, more and more folklore archives are being digitized. Given that scholarly data is increasingly being made available to the general public, it looks likely that this will also be the case for the scholarly archives of folklore performances, which will doubtlessly have many and various repercussions. In many ways, the USC Digital Folklore Archives is much like any other archive in terms of its data and its approach to collecting categorizations. Yet the simple act of having all the material in digital format, with complete global open access, creates something quite new, in step with the changes that are affecting much of our globe.

Folklore has seen a resurgence in relevance, as most of the cultural interchanges on the internet can be viewed as largely folkloric, especially in contrast to the print nationalism of modernity (as per Anderson i983). The role of the archives, then, shifts subtly from being at some remove from the people to being central to the discourse. Indeed, the folklorist Merrill Kaplan (20I3) has already noted the growth of "vernacular archives" such as snopes.com, and others, a trend that shows no signs of slowing down.

From my own perspective, I see the future of folklore studies aligning with the future of folklore archives, both of which will engage in the newer zeitgeist developing from the rapid globalization brought on by cyber communications. ${ }^{7}$ Material from the USC Folklore Archives has appeared in numerous books, research articles, blogs, news items, and more, from around the world. In bringing the material to everyday internet users, the considerable gap between scholars

7. See, e.g. the various publications in the books Folklore and the Internet (Blank ed. 2009), Tradition in the $2 I^{\text {st }}$ Century (Blank \& Howard eds. 20I3), and Folk Culture in the Digital Age (Blank ed. 20I2). 
and folk is lessened, and they increasingly become a part of the same enterprise. Still, I miss the pizza parties.

\section{Conclusion}

If the future is a foreign land, we are surely hurrying on our way there. I often say that I went into graduate school specializing in what was considered a somewhat "archaic" discipline, and I emerged from graduate school in what was considered a "cutting-edge" discipline. And it was not the discipline that had changed; rather, it was the world around it.

This epochal change has been described in this short tale of two archives. The first, the paper archives in Kroeber Hall, was founded to assert the contemporary relevance of folklore in a time of profound social and political upheaval, an exercise in multi-culturalism and inter-cultural exchange. The second, a digital archive, attempts to engage with the new cyber epoch of human culture, in which the lion's share of culture is now shared digitally, often globally.

While engaged in the processes of societal change themselves, archives are also products of that process, and represent different periods differently: premodern, modern, and some, now, post-modern. Archives have been around for quite some time, and there is no need to assume that they are no longer useful. But their utility will probably depend on how well archives can reflect the needs of society. Spivak suggested that the best way to let subalterns speak is to allow them access to the archives, and to use them in their own way. This, then, may help the subaltern speak. Á la mode de Derrida, the archons may become a much more inclusive group, allowing the people to have their own voice in their past cultural performances, and to make use of it in their own ways. This positioning of the archives can also contribute to increased transparency and awareness of what Charles Briggs labels the "metadiscursive practices" of our discipline.

I have attempted to stitch together a short story of our times, a tale of two California-based folklore archives with which I have been personally involved, on either side of the new millennium. This account highlights the changing roles of archives as part and parcel of the large-scale reformulations in the discipline of folklore studies, and in the very world surrounding them. 


\section{References}

ABRAHAMs, Roger (I993): "Phantoms of Romantic Nationalism in Folkloristics". Journal of American Folklore no. I06: I-37.

ANDERSON, Benedict (I99I) [1983]: Imagined Communities: Reflections on the Origins and Spread of Nationalism. New York: Verso Press.

Antonnen, Pertti (2005): Tradition through Modernity: Postmodernism and the Nation-State in Folklore Scholarship. Studia Fennica Folkloristica I5. Helsinki: Finnish Literature Society.

BENDix, Regina; Rosemary LÉvy-ZumWALT (I995): Folklore Interpreted: Essays in Honor of Alan Dundes. Berkeley: UC Berkeley Press.

BLANK, Trevor; Robert GLENN HOWARD (eds.) (20I3): Tradition in the 2Ist Century: Locating the Role of the Past in the Present. Logan: Utah State University Press.

BLANK, Trevor (ed.) (2009): Folklore and the Internet: Vernacular Expression in a Digital World. Utah State University Press. Logan, Utah.

- (ed.) (20I2): Folk Culture in the Digital Age: The Emergent Dynamics of Human Interaction. Boulder: Utah State University Press.

BRIGgS, Charles L. (I993): "Metadiscursive Practices and Scholarly Authority in Folkloristics". Journal of American Folklore no. I06: 387-434.

DerridA, J. (I996): Archive Fever: A Freudian Impression. Eric Prenowitz, transl. Chicago: U. of Chicago Press.

DUNDES, Alan (I97I): "A study of ethnic slurs: the Jew and the Polack in the US". Journal of American Folklore no. 84: 186-203.

- (I977): "The Curious Case of the Wide-mouth Frog". Language in Society no. 6: I4I-47.

- (I980): "Who Are the Folk?" In Interpreting Folklore by Alan Dundes. Bloomington: Indiana University Press.

- (2002): Bloody Mary in the Mirror: Essays in Psychoanalytic Folkloristics. Jackson: University of Mississippi Press.

— (2005): "Folkloristics in the Twenty-First Century". Journal of American Folklore no. II8: 385-408.

KAPLAN, Merill (20I3): "Curation and Tradition on Web 2.o." In Trevor BLANK and Robert GLENN HowARD (eds.): Tradition in the 2Ist Century: Locating the Role of the Past in the Present. Utah State University Press: Logan, p. I23-I48.

SPIVAK, Gayatri (I988): “Can the subaltern speak?" In Cary NELSON and Lawrence GROSSBERG (eds.): Marxism and the Interpretation of Culture. Urbana: University of Illinois Press, p. 27I-3I3.

ZuMWALT, Rosemary Lévy (2OI4): "Dundes Matters". Western Folklore no. 73: I39I 45 . 
A Tale of Two Archives, Two Eras...

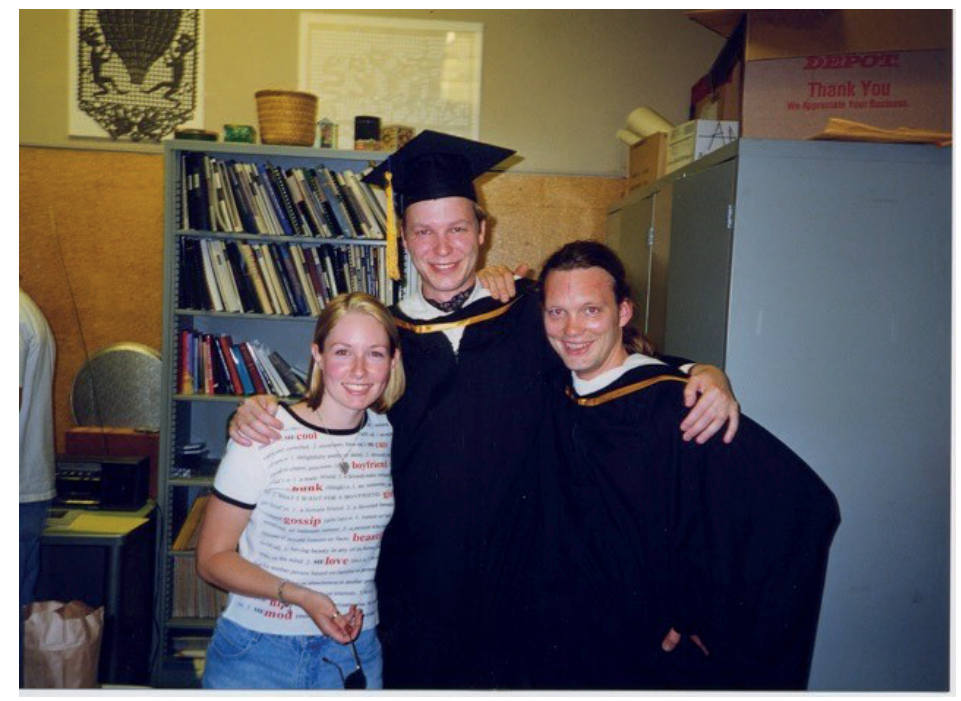

Graduation Party in the Archives (L-R), Lynne McNeill, Valdimar Tr. Hafstein, Tok Thompson. I999. 